IRA-International Journal of Management \&

Social Sciences

ISSN 2455-2267; Vol.17, Issue 01 (Q.1 2021)

Pg. no. 1-8.

IRA Academico Research

\title{
Status of Growth-Oriented Women Entrepreneurs in Indian Unorganized Sector
}

\section{Sakshi Saini}

Research Scholar, Centre for Studies in Economics and Planning, Central University of Gujarat, Gandhinagar, India.

Type of Work: Peer Reviewed.

DOI: https://dx.doi.org/10.21013/jmss.v17.n1.p1

\section{How to cite this paper:}

Saini, S. (2021). Status of Growth-Oriented Women Entrepreneurs in Indian Unorganized Sector. IRAInternational Journal of Management \& Social Sciences (ISSN 2455-2267), 17(1), 1-8. DOI: https://dx.doi.org/10.21013/jmss.v17.n1.p1

(C) IRA Academico Research.

(cc) BY-Nc This work is licensed under a Creative Commons Attribution-NonCommercial 4.0 International License subject to a proper citation to the publication source of the work.

Disclaimer: The scholarly papers as reviewed and published by IRA Academico Research are the views and opinions of their respective authors and are not the views or opinions of IRA Academico Research. IRA Academico Research disclaims of any harm or loss caused due to the published content to any party.

IRA Academico Research is an institutional publisher member of Publishers International Linking Association Inc. (PILA-CrossRef), USA. IRA Academico Research is an institutional signatory to the Budapest Open Access Initiative. Hungary advocating the open-access of scientific and scholarly knowledge. IRA Academico Research is a registered content provider under Open Access Initiative Protocol for Metadata Harvesting (OAI-PMH).

The journal is indexed \& included in WorldCat Discovery Service (USA), CrossRef Metadata Search (USA), WorldCat (USA), OCLC (USA), Open J-Gate (India), EZB (Germany) Scilit (Switzerland), Airiti (China), Bielefeld Academic Search Engine (BASE) of Bielefeld University, Germany, PKP Index of Simon Fraser University, Canada. 


\begin{abstract}
Women in India are still struggling for financial independence. Females in India accounted for 48\%, but their participation in the workforce is $26 \%$ (The Hindu, 2018). A significant proportion of the female labour workforce is engaged in the unorganized sector. The main reason for it is the informal sector flexibility to handle both work and household activity. In the Informal sector, enterprises are categorized as Own Account Enterprise (OAE, Enterprise do not hire any worker) and Establishments (enterprises which do hire any worker on a fairly regular basis). Many researchers referred to establishments as 'opportunity-Driven Enterprise' and 'Growth-oriented enterprise.' This paper will be focused on the status of Female-owned Established Enterprises all over the Indian states and in Manufacturing, Trade, and Other Services sector in India. This study is based on NSS 73rd round (2015-16). Most of the research on female entrepreneurs focused on their participation in Own Account Enterprises. This study is way forward to other studies because it focuses on growth-oriented enterprises than Necessity- Driven Enterprises, i.e., OAE.
\end{abstract}

ABSTRACT

Keywords: Unorganized enterprises, Establishments, growth-oriented enterprises, female proprietary

\title{
Introduction
}

Nine out of every ten working women in the Indian economy are part of the unorganized sector; balancing their lives plays an essential role in family and workplace (Hill, 2010). The Informal sector is a dominant feature of the world economy, likewise in India and other developing countries. Sixty-one percent of the world's working population is around two billion people working in the unorganized sector (ILO, 2018). These populations are exposed to social insecurities, vulnerable financial structures, and economic fluctuations. Informal employment is a more significant source for the male employer (63\%) than for women (58\%). Out of the two billion workers in informal employment worldwide, just over 740 million are women (ILO, 2018). Women are more exposed to informal employment, mostly in lower and middle-income countries, and more often in economically vulnerable situations. In the context of India, the informal sector is continually growing. The latest data estimated the number of enterprises in India's unorganized sector during 2015-16 as 6.34 crore. Economist's primary focus is finding a way to efficiently eradicate poverty and discuss why entrepreneurship is needed and emerging rapidly in low and middle-income countries. Schumpeter defines an entrepreneur as merely doing new things or transforming how things enhance productivity and encourage economic growth in a new way, i.e., Innovation (Schumpeter, 1947). Innovation is a 'creative response' whose introduction to entrepreneurs' market activities accelerates economic growth. However, it comes out more as a 'necessity' rather than a 'choice' consistently in developing and under-developed countries (Minniti, 2009). That is because of low education, low skill level, geographical compatibilities, and dis-comfortabilities, leading to shifting population from search of employment to self-owned business. A country's GDP is directly proportional to job opportunities within a country (Minniti, 2009). In developed countries, women choose to start an enterprise as an opportunity because the country is developed that can assist growth-oriented firms

Table 1- Percentage share of male and female proprietary in the Indian informal sector

\begin{tabular}{|c|c|c|c|c|c|c|}
\hline \multirow{3}{*}{ Gender } & \multicolumn{6}{|c|}{ Enterprises share in the Indian Informal Sector } \\
\hline & \multicolumn{3}{|c|}{ 2010-11 } & \multicolumn{3}{|c|}{ 2015-16 } \\
\hline & $\begin{array}{l}\text { Necessity-based } \\
\text { enterprises }\end{array}$ & $\begin{array}{l}\text { Growth-oriented } \\
\text { enterprises }\end{array}$ & All & $\begin{array}{l}\text { Necessity-based } \\
\text { enterprises }\end{array}$ & $\begin{array}{l}\text { Growth-oriented } \\
\text { enterprises }\end{array}$ & All \\
\hline Male & 76 & 89 & 78 & 74 & 90 & 76 \\
\hline Female & 20 & 5 & 17 & 22 & 5 & 20 \\
\hline All & 96 & 94 & 96 & 96 & 95 & 96 \\
\hline
\end{tabular}

The specific ownership categories covered by the survey were a proprietary, partnership, Self Help Group (SHG), and Trusts. Proprietary information was separately recorded based on the gender (including transgender) of the proprietor. $96 \%$ of ownership hold by male and female proprietary and the rest of $4 \%$ hold by transgender, SHG, and trusts 
The unorganized sector seems to be gender-biased in the ownership status of enterprises. Female holds only $20 \%$ share in running OAE (Own Account Enterprises) and 5\% in Establishments. On the other side, Male has the highest shares in both types of enterprises. Male holds the highest percentage of establishments over OAEs, which can be interpreted as Male pursue on 'growth-oriented enterprises' that is Establishments ( enterprises with at least one worker).

The disparity between the numbers of female and male-owned enterprises lies all over the world. The gap in ownership status between female-own enterprises and enterprises compared to men is consistent worldwide (Minniti, 2010); there are several reasons for inequality in employment and ownership status directly affected by various socio-economic characteristics like education, cultural background, Family wealth. If these factors can work out, then the gap between the contribution of both gender in economic activity can be dissipated (Blanch and Hower, 2004; cowling and Tayor, 2001). Green (2006) suggested that researchers should focus on more research rather than separate theory.

In traditional Indian society, women always represented as a giver, dedicated to her family. If a woman is uneducated due to factors like she belongs to a poor family, a conservative family where a girl child cannot go to school creates a vicious circle of underdevelopment.

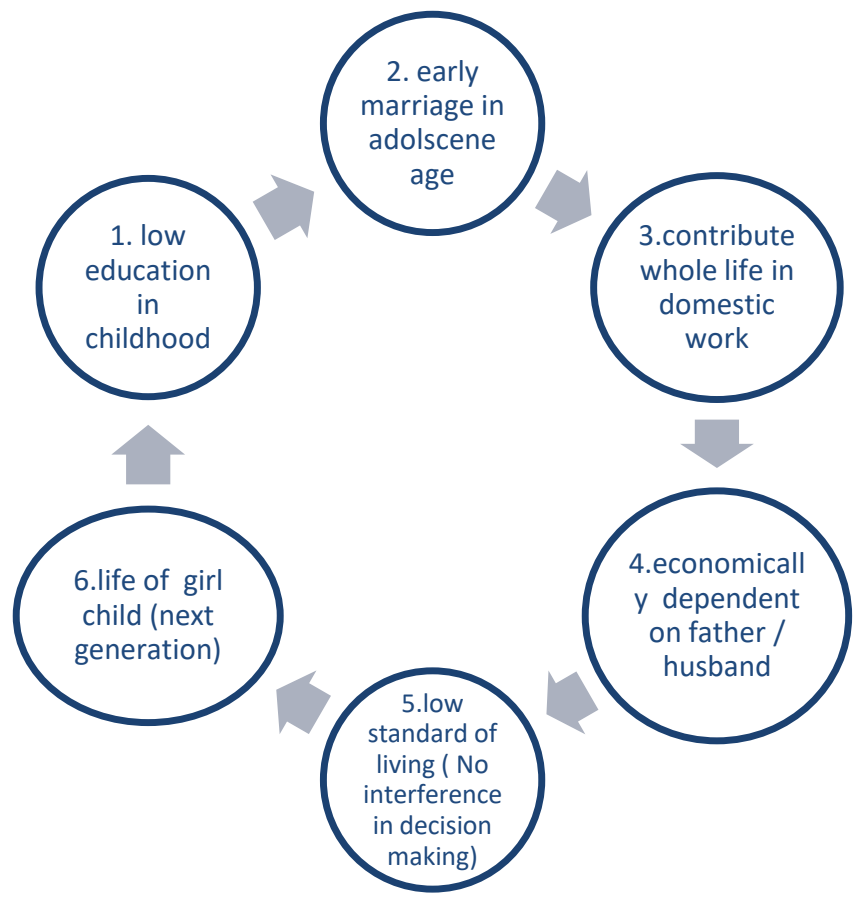

Source: Author

The present scenario in India and many other developing countries wherever women still do not have access to essential opportunities like education, job, and equal status to men. If we talk about the Indian context, entrepreneurs are emerging, but majorly, the male population is dominated. $48 \%$ of the people in India are female, but this representation in GDP is deficient. Women's contribution to the economy emerged majorly as necessity-based entrepreneurship rather than opportunity-based entrepreneurship (Daymard, 2015). In contrast, the research is more biased towards the necessity-driven factor (Shapera and Sokol, 1982).

\section{Research Gap}

After reviewing the literature, we have identified that majorly the existing research focuses on necessity-driven enterprises or own-account enterprises. Studies pointing out the need for development and technological advancement in own account enterprises are high in numbers, but productivity is low. The research on established enterprises still needs to be more focused as they are showing a positive growth rate (NSS report 
73rd round) for women entrepreneurs. These enterprises count few in numbers, but their productivity is higher than their account enterprises. The research will highlight the participation of women in both types of Enterprises. This research is also discussed women entrepreneurs' being less flexible while choosing business activity in the manufacturing, trade, and other services sectors. Secondly, the main research article talks about the various reasons for being in the informal sector.

\section{Research Objective}

- To determine the share of female and male-owned enterprises in own-account enterprises and establishments in Indian states.

- To discuss male and female proprietary share in three broad activity categories: manufacturing, trade, and other services.

\section{Research Methodology and Sources}

This research aims to analyze the status of women entrepreneurs in the informal sector of India. This research is based on secondary data provided by National Sample Survey Office and census. The National Sample Survey Office (NSSO), India, provides a comprehensive database on informal enterprises by gender of ownership through its Unorganized Non-agricultural enterprise's manufacturing, trade, and services surveys. The manufacturing units in the organized sector are surveyed by the Central Statistical Organization every year through the Annual Survey of Industries (ASI). In contrast, unorganized manufacturing and service establishments and own-account enterprises are separately surveyed by the 'National Sample Survey Organization (NSSO)' at five-year intervals. These surveys are the basis for many published reports on the state of Indian businesses and government agency monitoring of the Indian economy. The survey collects data from over 150,000 Indian enterprises.

The key estimates related to enterprises are extracted from the two published reports of NSS $73^{\text {rd }}$ round, i.e., "Operational characteristic of unincorporated Non- Agriculture Enterprises (excluding construction) in India" and "Economic characteristics of unincorporated Non- agricultural enterprises (excluding construction) in India."

\section{Finding of the study}

The table below shows that the proprietary shares held by male and female entrepreneurs in Own Account Enterprises (Enterprises do not hire any worker) and Establishments (Enterprises that hire at least one worker at fair wages).

Table 2: Regional Pattern of enterprise ownership

\begin{tabular}{|c|c|c|c|c|c|c|}
\hline \multirow{3}{*}{ States } & \multicolumn{6}{|c|}{ Proprietary Share } \\
\hline & \multicolumn{3}{|c|}{$\begin{array}{l}\text { Necessity-based enterprises } \\
(\%)\end{array}$} & \multicolumn{3}{|c|}{$\begin{array}{l}\text { Growth-oriented } \\
\text { enterprises(\%) }\end{array}$} \\
\hline & Male & Female & All & Male & Female & All \\
\hline North-India Region & 88 & 12 & 98 & 92 & 4 & 95 \\
\hline West-India Region & 76 & 22 & 97 & 91 & 4 & 94 \\
\hline Central Region & 84 & 14 & 98 & 93 & 3 & 96 \\
\hline East Region & 71 & 26 & 97 & 91 & 3 & 94 \\
\hline North-East Region & 83 & 15 & 98 & 88 & 10 & 98 \\
\hline South India Region & 62 & 31 & 93 & 87 & 7 & 93 \\
\hline Union Territory & 83 & 14 & 97 & 90 & 7 & 97 \\
\hline All-India & 74 & 22 & 96 & 90 & 5 & 95 \\
\hline
\end{tabular}

Source: NSS $73^{\mathrm{RD}}$ Round, 2015-16

Women are facing constant barriers in realizing their entrepreneurial potential in ownership of establishments. The regional pattern shows the broader gap between the percentage of female entrepreneurs heading Establishments and Own Account Enterprises. However, this gap is narrowing down in absolute terms of 
female-headed own account enterprises. The percentage of female-owned Own Account Enterprises is 22.3\%, and the Establishments are $4.8 \%$ at all Indian level. Own Account enterprises owned by both male and female entrepreneurs are $96 \%$. The rest of them is owned by SHGs, NGOs, Transgender, and other groups. These barriers can be due to social acceptance of working women or lack of education. Women's share in the total labour force has risen. With a fall in women's participation in agriculture in most countries, an increasing number of women turn to the non-agricultural sector for jobs, informal sector turning to be a great escape for them (Khema, 2012). There is a need for the full utilization of human capital to acquire potential economic growth.

The share of male and female entrepreneurs in different enterprise type

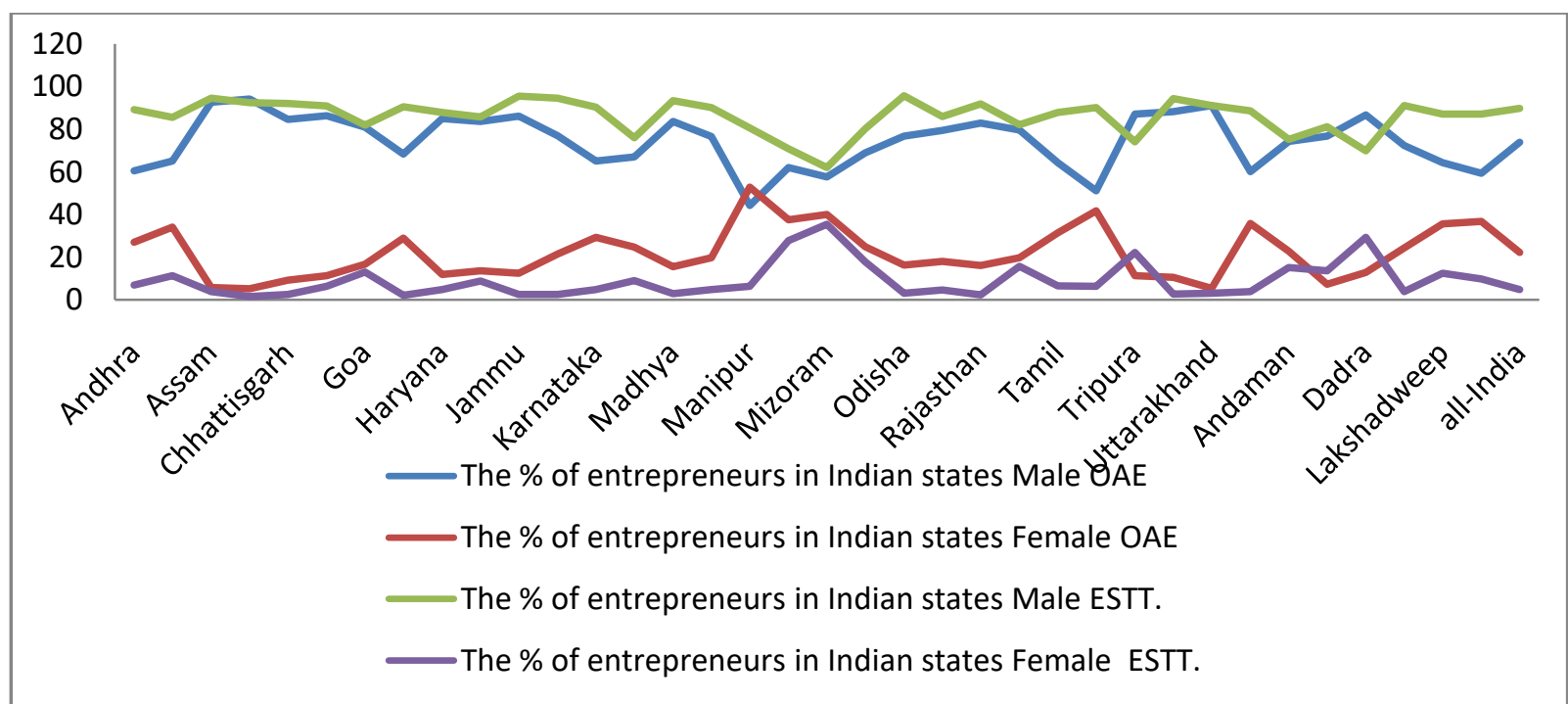

Source: NSS 73 ${ }^{\text {rd }}$ Round, 2015-16

Manipur has the highest number of female-owned enterprises without workers (52\%) (own account enterprises). Mizoram has the highest number of female-owned enterprises with the worker (35\%) in establishments. High level of female proprietary enterprises evident in north-eastern Indian States Manipur (52\% female-owned OAE, $7 \%$ of establishment), Mizoram (40\% female-owned OAE, 3.9\% of female-owned establishment), Meghalaya ( $37.7 \%$ of OAE, $16 \%$ of establishments). These states have a higher number of own-account enterprises, but the number of establishments is higher than all India's average of the female-owned establishment (4.8\%). Except for Assam, females' contribution to economic activity reflects gender equality, which benefits long-run growth. North Indian State and Eastern State have a low level of women's participation as entrepreneurs. Bihar constitutes only $5.3 \%$ OAEs owned by women and $1.6 \%$ establishments, which is the lowest among these two categories of enterprises. States like Bihar, Uttarakhand, Rajasthan, Gujarat, Assam, and Jharkhand need future investment in human resources to enhance women's participation.

\begin{tabular}{|l|r|l|r|}
\hline \multicolumn{5}{|c|}{$\begin{array}{l}\text { Share of Growth-oriented enterprises(Establishment) in Indian } \\
\text { States }\end{array}$} & \multicolumn{1}{|l|}{$\begin{array}{l}\text { Male } \\
\text { Proprietary }\end{array}$} & $\begin{array}{l}\text { Female } \\
\text { Proprietary }\end{array}$ & All \\
\hline State & 96 & 3 & 98 \\
\hline Jammu \&Kashmir & 86 & 9 & 95 \\
\hline Himachal Pradesh & 88 & 5 & 93 \\
\hline Haryana & 94 & 3 & 97 \\
\hline Uttar Pradesh & 91 & 3 & 94 \\
\hline Uttarakhand & & &
\end{tabular}


IRA-International Journal of Management \& Social Sciences

\begin{tabular}{|c|c|c|c|}
\hline Punjab & 86 & 5 & 91 \\
\hline North-India Region & 92 & 4 & 95 \\
\hline Rajasthan & 92 & 2 & 94 \\
\hline Gujarat & 91 & 2 & 93 \\
\hline Maharastra & 90 & 5 & 95 \\
\hline Goa & 82 & 13 & 95 \\
\hline West-India Region & 91 & 4 & 94 \\
\hline Madhya Pradesh & 93 & 3 & 96 \\
\hline Chattisgarh & 92 & 3 & 95 \\
\hline Central Region & 93 & 3 & 96 \\
\hline Bihar & 92 & 2 & 94 \\
\hline Jharkhand & 95 & 3 & 97 \\
\hline west Bengal & 89 & 4 & 93 \\
\hline Odisha & 96 & 3 & 99 \\
\hline East Region & 91 & 3 & 94 \\
\hline Arunachal Pradesh & 86 & 11 & 98 \\
\hline Assam & 95 & 4 & 99 \\
\hline Meghalaya & 71 & 28 & 99 \\
\hline Manipur & 81 & 6 & 87 \\
\hline Mizoram & 62 & 35 & 98 \\
\hline Tripura & 74 & 22 & 96 \\
\hline Nagalnd & 80 & 18 & 98 \\
\hline Sikkim & 82 & 16 & 98 \\
\hline North-East Region & 88 & 10 & 98 \\
\hline Andra Pradesh & 89 & 7 & 96 \\
\hline Karnataka & 90 & 5 & 95 \\
\hline Tamil Nadu & 88 & 7 & 95 \\
\hline Kerala & 76 & 9 & 85 \\
\hline Telangana & 90 & 6 & 97 \\
\hline South India Region & 87 & 7 & 93 \\
\hline Andaman \& Nicobar & 75 & 15 & 90 \\
\hline Chandigarh & 81 & 14 & 95 \\
\hline Dadra & 70 & 29 & 99 \\
\hline Daman \&diu & 91 & 4 & 95 \\
\hline Lakshadweep & 87 & 12 & 100 \\
\hline Puducherry & 87 & 10 & 97 \\
\hline Delhi & 91 & 6 & 97 \\
\hline
\end{tabular}


IRA-International Journal of Management \& Social Sciences

\begin{tabular}{|l|r|r|r|}
\hline Union Territory & 90 & 7 & 97 \\
\hline \multicolumn{5}{|c|}{} \\
\hline All-India & 90 & 5 & 95 \\
\hline
\end{tabular}

Source: NSS $73^{\text {rd }}$ Round, 2015-16

The above figure shows the ownership status of male and female entrepreneurs in Indian states. Female entrepreneurs' participation has doubled over the past ten years. It was about 10 million in the non-agricultural sector, primarily due to the rise in enterprises without workers (Daymard, 2015). Their share rose in all sectors, and women now account for nearly half of total entrepreneurs without manufacturing workers. Their claims have also grown in services and trade but remained modest at about $10 \%$ of the total. Given the often marginal nature of these activities, this can result from a lack of wage employment opportunities elsewhere in the Indian economy. This figure clearly shows that the number of own-account enterprises is higher than in establishments. The female-owned establishments are highest in Mizoram with 35.4\%, followed by Dadar 29.3\% and Meghalaya $27.8 \%$. The females in states of the north-eastern region have significant participation in business activities. e. Women's share in the total labour force has risen. With a fall in women's participation in agriculture in most countries, an increasing number of women turn to the non-agricultural sector for jobs, most of which are located in urban areas (Khema, 2012).

Bihar has the lowest percentage of female Entrepreneurs in both OAE (5.3\%) and establishment (1.6\%). Whereas, in the east region itself, the other states like Jharkhand (21.5\%), West Bengal (35.9), and Odisha $(16.4 \%)$ having a significant share of female entrepreneurs in OAEs.

The status of the north-eastern region in the share of female entrepreneurs in both enterprise types is impressive. Manipur (52.9\%), Mizoram (40.1\%), Arunachal Pradesh (34.1\%), Meghalaya (37.7\%) in OAE enterprise type. The high percentage of OAE enterprise is also because most of the enterprise in the household itself. It is more comfortable for women to balance between family responsibility and work.

\section{Gender differentials in ownership status in broad activity category}

The informal sector broadly covers the three economic sectors: Manufacturing, trade, and other services. In these sectors, $84.2 \%$ of enterprises are Own Account Enterprises, and the rest $15.8 \%$ of the enterprises' nature are establishments (i.e., the enterprises that employ hired workers on a fairly regular basis). The share of OAEs dominates the three broad activity categories; 'Manufacturing' (85.5\%), 'Trade' (84.5\%), and 'Other Services' $(82.5 \%)$.

Table: Percentage of Entrepreneurs in Different Activity Category

\begin{tabular}{|l|l|l|l|l|l|l|l|}
\hline \multirow{2}{*}{ BAC } & \multicolumn{3}{l}{$\begin{array}{l}\text { Necessity-based entrepreneurs } \\
\text { (OAE) }\end{array}$} & \multicolumn{2}{l}{$\begin{array}{l}\text { Growth-oriented } \\
\text { Enterprises(Establishments) }\end{array}$} \\
\cline { 2 - 8 } & Male & Female & All & Male & Female & All \\
\hline Manufacturing & 47 & 52 & 99 & 91 & 5 & 96 \\
\hline Trade & 88 & 10 & 98 & 92 & 3 & 95 \\
\hline Other Services & 84 & 8 & 92 & 87 & 6 & 93 \\
\hline All & 74 & 22 & 96 & 90 & 5 & 95 \\
\hline
\end{tabular}

Female proprietary ownership is higher than male proprietary in manufacturing activities, but they are confined only to particular activity categories. These activities are categories as traditional activities and primarily operate within the household and without workers. The unorganized sector accounts consist for over $99 \%$ of Indian manufacturing establishments (Ghani, 2013). 91\% of the total male entrepreneurs engage in manufacturing establishments, and share in trade and other services for establishments are $92 \%$ and $87 \%$, respectively. Table 3.1 shows a contrary situation in percentage shares of the ownership status of male and female entrepreneurs. The male entrepreneurs have their dominance in enterprises with workers, which have high productivity and high capital intensity compared to OAEs.

\section{Conclusion}

Women's role in the Indian economy still lags behind developed economies (World Bank, 2011). "World Bank Entrepreneurship Snapshots" report finds that India's entrepreneurship rate is lower than its stage of 
development; similar comparisons also highlight that India's gender ratio among entrepreneurs is lower than its peers. This dual under-performance has a cultural and economic background, but it is starting to change for good. Women are making economic gains in the Indian economy, and further progress represents a tremendous growth opportunity for the country(World Bank,2011). The economic condition can not be solved in a day. Overall, institutional requirements also need to be improved. One aspect is 'culture'; role models and social context strongly influence entrepreneurs. It is crucial to promote business-women as role models in society and ensure that the education system is gender-neutral and should encourage women to go into STEM fields: science, technology, engineering, and mathematics (OECD,2015). at last, more effective actions should be taken to ensure that family policies, social policies, and tax policies favor filling the gender gap in entrepreneurship by women.

\section{References}

[1]. Working Papers. Vol. 1191. OECD Economics Department Working Papers, March 12, 2015. https://doi.org/10.1787/5js4rfh5gtbq-en.

[2]. Ghani, Ejaz, William R. Kerr, and Stephen D. O'Connell. Female Business Ownership and Informal Sector Persistence. Policy Research Working Papers. The World Bank, 2013. https://doi.org/10.1596/1813-9450-6612.

[3]. Minniti Maria. Female Entrepreneurship and Economic Activity. The European Journal of Development Research 22, no. 3 (July 2010): 294-312. https://doi.org/10.1057/ejdr.2010.18.

[4]. Gender Issues in Entrepreneurship. Foundations and Trends® in Entrepreneurship 5, no. 7-8 (2009): 497-621. https://doi.org/10.1561/0300000021.

[5]. Schumpeter, Joseph A. The Creative Response in Economic History. Joseph A. Schumpeter, n.d., 11.

[6]. Ghani, Ejaz, William R. Kerr, and Stephen D. O'Connell. Local Industrial Structures and Female Entrepreneurship in India. Journal of Economic Geography 13, no. 6 (November 2013): 929-64. https://doi.org/10.1093/jeg/lbt004.

[7]. Klapper, L. F., and S. C. Parker. Gender and the Business Environment for New Firm Creation. The World Bank Research Observer 26, no. 2 (August 1, 2011): 237-57. https://doi.org/10.1093/wbro/lkp032.

[8]. Arnaud, Determinants of Female Entrepreneurship in India. OECD Economics Department Working Papers. Vol. 1191. OECD Economics Department Working Papers, March 12, 2015. https://doi.org/10.1787/5js4rfh5gtbq-en. 